\title{
FOREST FIRE PROTECTION IN CANADA
}

\author{
by Donald Angus Macdonald,
}

B.Sc.F. University of New Brunswick 1914, Chief Division of Forest Protection, Dominion Forest Service Alberta, British Columbia, Manitoba, Saskatchewan, 1914 to 1928. Head Office 1928 to date.

II

$\mathrm{N}$ view of the prominent place held by Canada in the world's timber ex-

port trade and her world leadership in the export of newsprint paper, as well as the leading part taken by the forest industry in her internal trade (where it ranks second only to agriculture), it is but natural that in the deliberations of each British Empire Forestry Conference the protection of Canada's forests from fire has been a subject of considerable discussion. No doubt there are many present who attended the British Empire Forestry Conference of 1,923 who will recall their extensive journeys in Canada that year which enabled them to observe for themselves, at first hand, the havoc wrought by forest fires, and at the same time to recognize the need for controlling them. They also realized, as all foresters in Canada do, that the forest fire problem is the chief obstacle to the practice of forestry in Canada.

\section{SUMMARY OF 1923 CONFERENCE REPORT ON FOREST PROTECTION}

Since the recommendations contained in the report of that comnittee were in a large measure responsible for the trend and development of fire protection in this country since that date, it is essential at this stage to review briefly the salient points of that report.

After stressing the general importance of forest protection the report emphasized the following points:-

(1) That permanent dedication of absolute forest lands is necessary in order that protection plans may be built upon stabilized conditions;

(2) That a definite forest policy of direction of settlement in forest regions on a community basis should be followed, in preference to permitting indiscriminate locations;

(3) That Fire Prevention offers the only means of enlisting the wholehearted support and co-operation of the general public, without which the solution of the fire problem is not possible; and that educational work on fire prevention in the schools and general publicity extensive enough to teach all classes of the population should be undertaken; 
(4) That the proper disposal of slash in one form or another is quite feasible in all parts of Canada, excepting, possibly, the Pacific Coast, where its utility had not been finally determined; and that a conference of the provincial ministers of the Crown responsible for forest administration with their chief foresters and federal representatives, meeting together with representatives from the forest industries, should be held with the idea that such a meeting might lay down a fixed course of action regarding slash disposal.

Dealing with "Fire Control" the report enlarged on the need for unification of authority in the organization responsible for fire protection, recommended the adoption of burning-permit requirements, and suggested that fire-report forms be standardized in order that statistical data may be intelligently compiled.

The use of aircraft in forest protection (in its infancy in 1923) was commented on, and governments were urged to grant special assistance in order that further use might be made of them.

The report concluded with the statement that conditions in Canada and in certain other parts of the Empire with regard to forest fire protection were unsatisfactory, but hopeful signs existed, and that, given public and governmental support, the forest authorities could handle the situation which confronted them.

\section{SUMMARY OF PROGRESS, 1923-1928}

In the five years which followed the 1923 Conference, substantial improvements took place in the various phases of forest protection in this country. 'The fire season of 1923 was one of the most disastrous on record, from the standpoint of fire losses. This fact, combined with the prestige given our forestry problems by the Conference itself, accounted in a large measure for the progress which resulted. The most notable advance observed was in the field of fire prevention.

Beginning in the late winter of 1922-3, by Royal Proclamation, the first "Save-the-Forest Week" was established in April of that year. These shortterm high-pressure campaigns with definite objectives appealed to the press of the country, which gave them enthusiastic support, and provided the element of news value.

In 1926, the "Save-the-Forest Week" campaign (which had its inception in the United States in 1920) was expanded and attained an international character by the combining of the United States and Canadian forest weeks, the dates of the campaigns being synchronized.

The most interesting feature of the 1928 campaign was the exchange of speakers by the two countries. The addresses delivered by outstanding public 
men naturally possessed high news value and came in for wide publicity in both countries. These campaigns, while they employed radio, posters, the co-operation of schools, and other features, stressed the importance of newspaper publicity. The goodwill of the press was the more easily secured by the fact that substantial funds were provided for advertising. The expenditure for this item alone in 1928 exceeded $\$ 27,000$.

In addition to the periodic "Save-the-Forest Week" campaigns, steady and consistent propaganda was carried on throughout the entire year. This took the form of exhibits, with distribution of forestry literature, at industrial and agricultural fairs, public lectures, motion pictures, and pamphlets designed to enlist the support of the younger generation.

In the province of Manitoba, through a co-operative arrangement between educational authorities of that province and the Dominion forest service, lecture courses were included as part of the regular training of students in one of the normal schools, and students were required to pass a regular examination in the subject of forestry. As a result one hundred and seventy-five school teachers in Manitoba were equipped with a teaching knowledge of forestry.

An eventful meeting which gave impetus to the "forest-week" campaigns and paved the way for better forest protection in Canada was the "Forest Fire Conference of 1924." Convoked by the then Minister of the Interior, who acted as chairman, it sat for five successive days, and held nine full sessions in addition to many meetings of committees. Thirty-four authorized delegates attended this gathering which included Ministers of the Crown of all the provinces administering their own natural resources, the chief foresters of those provinces, and many federal government officials. This gathering was the direct outcome of the suggestion contained in the report of the committee on fire protection of the second British Empire Forestry Conference. Representatives of the forest industries were not included, since it was felt that the several forest authorities in Canada should first have an opportunity of correlating their views and agreeing in matters of general policy before approaching the industries. The discussions were informal but frank expositions of the fire problem as it affected the various provinces individually and the Dominion as a whole. The deliberations of the Conference focused attention on the report of the fire-protection committee of the second British Empire Forestry Conference and the suggestions contained therein already enumerated. These formed the basis of the resolutions adopted, and defined a common line of action by the forest authorities of Canada for the improvement of the fire situation.

The ensuing years saw many of these resolutions carried out in full or in part. Some of the more involved, however, including direction of settle- 
ment, uniform slash disposal, and land classification, are by their very nature problems requiring many years for satisfactory solution.

The Conference had the effect of bringing together for the first time the various authorities charged with forest protection, and the personal contacts gained were successful in promoting a better understanding, a clearer conception of the problems and difficulties facing the various government authorities, and a thorough appreciation of the need for concerted action by all concerned.

Summing up the progress of fire protection for the period of 1923-28 inclusive, one may say that in 1923 the forest fire situation in Canada was unsatisfactory. By 1928 the situation was greatly improved, owing largely to the fact that six years of fairly intensive propaganda and publicity on forest protection had roused public opinion to the need for action to save the forest from destruction. This appreciation on the part of the general public and governments reacted to the benefit of forest-protection organizations, and was reflected in the increased funds provided for that purpose. Fire-fighting technique progressed correspondingly with additional and improved equipment, and added facilities in the form of general improvements in transport.

Throughout the five years following 1923 weather conditions were favourable to the protection forces, particularly in the years 1927 and 1928, so that at the latter date the outlook for the future was bright.

\section{PROGRESS FROM 1929 to 1935}

The period from 1929 to 1934 inclusive will long be remembered as the most difficult ever experienced in the history of organized fire protection, and in reviewing the progress of protection in that time a brief reference is necessary to two factors which infuenced the developments of that period, namely unusual climatic conditions and the world-wide depression.

Beginning in 1929, there followed for the next five years a period of unprecedented drought, during which over large areas there was a continuous lack of both winter and summer precipitation. This situation was further aggravated by extreme temperatures and high winds during the fire season from May to October. The Dominion suffered as a whole, but fortunately periods of extreme hazards were not prevalent over all parts of Canada in the same year, but shifted from east to west or vice versa. Needless to say, these dry years resulted in a general lowering of the water table and several wet years will be required to restore and replenish thousands of sloughs, small lakes, and streams which have since disappeared. Coincident with these abnormally dry years was a corresponding increase of the forest-fire hazard, beginning in 1929, a season of unusual severity in western Canada. In 1930, the number of fires increased, and heavy losses were registered in both the eastern and 
the western sections. During these years the prevailing weather conditions were conducive to lightning fires, and a record number was attributed to this cause. In 1931, some improvement was noted in Eastern Canada, but heavy losses occurred in the extreme West. This order was reversed in 1932, when conditions remained normal in the west, with heavy losses in Central and Eastern Canada. An interesting feature of this year was the record number of fires attributed to incendiarism, occurring as they did in the low point of depression. The years 1933 and 1934, on the whole, showed a general improvement over previous years, except in the Maritime Provinces. Here weather conditions were extreme, and fires and fire losses attained record proportions for New Brunswick and Nova Scotia.

Following closely behind the critical dry years came the world-wide depression, bringing with it economic conditions without parallel in modern times. In spite of the handicap imposed by both physical and financial conditions, due credit must be given to the protection staffs, working with facilities that were barely sufficient for attaining the measure of control obtained. New and hard lessons were learned in the field of fire-fighting, and in this respect, if in no other, it can be said progress was made in protection during the period under consideration.

\section{CHANGE OF FOREST AUTHORITY, 1930}

From the time of its inception-about 1900-until 1930, one of the most important activities of the Dominion Forest Service consisted in the protection and administration of the forest lands in the provinces of Manitoba, Saskatchewan and Alberta, and the Railway Belt and Peace River Block of British Columbia. However, late in 1930 the natural resources of these four western provinces were transferred from Dominion to provincial control.

In each of the first three provinces mentioned a new provincial forest service was set up and for the most part these provinces absorbed the existing. Dominion Forest Service staff into their new organizations. In British Columbia the case was somewhat different, since that province had organized its. own Forest Service in 1912, so that the transfer simply meant an increase of about 18 per cent in their patrol area consqeuent upon the absorption of the Railway Belt and the Peace River Block.

The situation with regard to forest authority in Canada since 1930 is that each of the nine provinces (exceptng only Prince Edward Island, which has no forest lands) has its own provincial forest service. It follows that the administration and protection of forests is now practically entirely a provincial function. Of the Crown lands remaining under Dominion jurisdiction, the Department of Indian Affairs administers the forests on the Indian reserves, 
and three branches of the Department of the Interior administer, respectively, the National Parks, the Northwest Territories and Yukon Territory, and the Dominion Forest Experiment Stations.

\section{AIRCRAFT}

The first experiments with aircraft for forestry purposes in Canada took place in 1919, when obsolete war machines were employed. These experiments were made possible by the co-operation of the Forest Service, Department of the Interior, and the Royal Canadian Air Force, Department of National Defence. By 1928 this co-operative arrangement was much expanded and a high stage of development had been reached. Some 24 aircraft were employed in the three western provinces of Manitoba, Saskatchewan, and Alberta, where they were found to have a definite and useful place in forest protection.

Many improvements both in performance and method of employment took place, including a specially designed light aircraft for detection and larger, more powerful machines for transporting fire crews. The peak of performance was reached in 1930, when a transportation machine made its appearance which for the first time solved the problem of carrying an effective fire crew to a fire in one trip.

The co-operative efforts of the Dominion Forest Service and the Royal Canadian Air Force came to an end with the transfer of resources late in 1930, when the Royal Canadian Air Force was withdrawn from the forestry field in the three prairie provinces.

\section{FOREST-FIRE RESEARCH}

The forest fire-hazard research initiated by the Federal Service in 1926 at its Petawawa Forest Experiment Station has achieved a marked degree of success. This scientific approach to "fire prevention" consists of the study and unvestigation of the influence of weather factors upon the inflammability of the materials composing the forest floor, in which fires start and spread. The inoisture content of these forest fuels depends entirely on the weather. By observing relationships which exists between the moisture content of these anaterials and the various weather factors, tables have been developed for computing an index or measure of forest inflammability. It is now possible by the aid of these tables, and a daily record of rainfall, rate of evaporation, and relative humidity of the air, to compute each day the index of inflammability which exists in any type of forest for which the necessary data have been collected. This index of inflammability can be shown in graphical form and is then termed a fire-hazard chart. Investigations have been completed in the 
pine types-i.e., red, white, and jack pine and their various mixtures-and extended to the mixed hardwood and open grassy subtypes at the Petawawa Forest Experiment Station.

As a result of many tests, zones of inflammability have been established covering the fuel-moisture contents of these types. These zones are designated as Nil, Low, Moderate, High, and Extreme.

The object of the study is to provide, ultimately, a fire-weather forecast which will enable those charged with fire protection to make their plans in advance for the detail of forest employees so that they may be strategically located in accordance with the degree of inflammability which exists in the forest, to regulate the issuance or cancellation of travel permits and burning permits to regulate frequency of forest patrols, and to know when lookouttower men may be relieved of duty. The use of this knowledge, which is a scientific measure of fire-hazard, is designed to preclude guess-work in forest management. This method has been in practical field use for the past six years in a number of localities in Eastern Canada with considerable success. Tests of this system have indicated an accuracy of from 96 to 99 per cent in determining the probability of occurrence and behaviour of forest fires: A further improvement in technique has taken place in the past two years with the

TABLE I.-FOREST FIRE LOSSES

\begin{tabular}{|c|c|c|c|c|c|c|c|}
\hline \multirow[t]{2}{*}{ Year } & \multirow[t]{2}{*}{$\begin{array}{l}\text { Total } \\
\text { No. } \\
\text { fires }\end{array}$} & \multirow{2}{*}{$\begin{array}{c}\begin{array}{c}\text { Total } \\
\text { area } \\
\text { burned }\end{array} \\
\text { Acres }\end{array}$} & \multirow{2}{*}{$\begin{array}{c}\begin{array}{c}\text { Merchant- } \\
\text { able timber } \\
\text { area }\end{array} \\
\text { Acres }\end{array}$} & \multicolumn{2}{|c|}{$\begin{array}{l}\text { Amount of } \\
\text { merchantable timber }\end{array}$} & \multirow{2}{*}{$\begin{array}{c}\begin{array}{c}\text { Estimated } \\
\text { stumpage } \\
\text { value }\end{array} \\
\$\end{array}$} & \multirow{2}{*}{$\begin{array}{c}\begin{array}{c}\text { Young } \\
\text { growth } \\
\text { area }\end{array} \\
\text { Acres }\end{array}$} \\
\hline & & & & M ft. B.M. & Cords & & \\
\hline 1925. & 5,400 & $1,913,066$ & 300.015 & 995,896 & 742,893 & $4,826,565$ & 499,988 \\
\hline 1926. & 5,690 & $1,824,015$ & 575,732 & 640,253 & $3,396,720$ & $4,208,456$ & 525,796 \\
\hline 1927 & 3,605 & 471,878 & 114,708 & 73,160 & $1,397,241$ & 831,492 & 137,124 \\
\hline $1928 \ldots \ldots \ldots \ldots \ldots$ & 4,261 & $1,345,371$ & 217,451 & 48,617 & 631,885 & 417,883 & 374,155 \\
\hline $1929 \ldots \ldots \ldots \ldots$ & 6,685 & $6,029,665$ & 663,574 & 508,715 & $2,005,386$ & $2,379,582$ & $1,092,442$ \\
\hline $\begin{array}{r}\text { 5-year average } \\
1925-1029 \ldots \ldots \ldots\end{array}$ & 5,146 & $2,316,799$ & 374,296 & 455,128 & $1,634,825$ & $2,532,796$ & 525,901 \\
\hline $1930 \ldots$. & 6,805 & $2,670,249$ & 746,129 & 663,315 & $1,988,109$ & $4,452,390$ & 577,982 \\
\hline $1031 \ldots \ldots$ & 6,954 & $2,093,869$ & 394,818 & 230,347 & $1,104,049$ & $1,715,182$ & 590,227 \\
\hline $1932 \ldots$ & 6,295 & $2,463,608$ & 708,085 & 549.872 & $2,619,453$ & $5,056,983$ & 586,141 \\
\hline $1933 \ldots$ & 6,298 & $1,008,557$ & 204,405 & 255,383 & 650,317 & $1,199,305$ & 220,620 \\
\hline $1934 \ldots$ & 5,911 & $1,475,117$ & 321,414 & 000,002 & 863,554 & $1,756,701$ & 242,101 \\
\hline $\begin{array}{c}\text { 5-year average } \\
1030-1034 \ldots \ldots \ldots \ldots\end{array}$ & 6,453 & $1,942,280$ & 474,970 & 519,784 & $1,445,096$ & $2,836,112$ & 443,414 \\
\hline $\begin{array}{r}\text { Grand Total } \\
1925-1934 \ldots \ldots\end{array}$ & 57,904 & $21,295,395$ & $4,246,331$ & $4,874,560$ & $15,399,607$ & $26,844,539$ & $4,846,576$ \\
\hline $\begin{array}{c}10 \text {-year average } \\
1025-1934 \ldots \ldots \ldots \ldots\end{array}$ & 5,709 & $2,129,539$ & 424,633 & 487,455 & $1,539,061$ & $2,684,454$ & 484,658 \\
\hline
\end{tabular}


development of a slide-rule, by means of which the daily hazard may be obtained in a few minutes.

The work is being vigourously prosecuted, and studies have been extended this year (1935) to the pulpwood forests of Quebec. It is ultimately hoped to cover the main climatic and forest types in Canada.

\section{FOREST FIRES}

One of the recommendations of the Committee on Fire Protection of the second British Empire Forestry Conference (Canada 1923) suggested that fire-report forms should be standardized in order that statistical data might be intelligently compiled. This suggestion has been carried out to a very large extent. The 1924 forest-fire conference agreed that action in this direction should be taken, and the Dominion Forest Service was delegated to act as a clearing-house through which standardized information should be collected and disseminated.

This information is now submitted to the Federal Service each year by the various provinces and protective organizations in Canada. From the data so secured Table I, showing the forest-fire losses in Canada for the past ten-year period (1925 to 1934 inclusive), has been compiled:-

IN CANADA, 1925-1934, INCLUSIVE

\begin{tabular}{|c|c|c|c|c|c|c|}
\hline $\begin{array}{l}\text { Value of } \\
\text { young } \\
\text { growth }\end{array}$ & $\begin{array}{l}\text { Cut-over } \\
\text { area } \\
\text { burned }\end{array}$ & $\begin{array}{l}\text { Value timber } \\
\text { and Y.G. lost } \\
\text { in cut-over }\end{array}$ & $\begin{array}{l}\text { Value } \\
\text { of other } \\
\text { property }\end{array}$ & $\begin{array}{l}\text { Non- } \\
\text { forested } \\
\text { area }\end{array}$ & $\begin{array}{c}\text { Cost of } \\
\text { actual } \\
\text { fire-fighting }\end{array}$ & $\begin{array}{l}\text { Total loss } \\
\text { including } \\
\text { fire-fighting }\end{array}$ \\
\hline$\$$ & Acres & $\$$ & $\$$ & Acres & $\$$ & $\$$ \\
\hline $1,118,700$ & 201,000 & 97,000 & 701,624 & 912,063 & 860,415 & $7,604,304$ \\
\hline $1,244,266$ & 240,507 & 181,000 & 967,335 & 481,980 & 866,286 & $7,467,343$ \\
\hline 193,481 & 35,875 & 36,449 & 91,670 & 184,171 & 242,963 & $1,396,055$ \\
\hline 508,419 & 59,631 & 49,995 & 147,288 & 694,134 & 205,365 & $1,328,950$ \\
\hline $2,004,759$ & 720,910 & 285,569 & 310,499 & $3,552,739$ & $1,239,345$ & $6,219,754$ \\
\hline $1,013,925$ & 251,585 & 130,003 & 413,683 & $1,165,017$ & 682,875 & $4,803,281$ \\
\hline $1,456,134$ & 427,286 & 275,579 & 506.777 & 918,852 & $1,135,907$ & $7,826,787$ \\
\hline $1,217,538$ & 535,406 & 220,366 & 363,516 & 573,418 & 931,518 & $4,448,120$ \\
\hline $1,209,063$ & 772,625 & 615,605 & 264,769 & 396,757 & 683,650 & $7,830,070$ \\
\hline 454,648 & 331,614 & 187,303 & 162,075 & 251,918 & 509,939 & $2,513,270$ \\
\hline 573,469 & 562,446 & 246,031 & 149,923 & 349,156 & 827,451 & $3,553,575$ \\
\hline 928,170 & 525,875 & 308,975 & 289,412 & 408,020 & 817,693 & $5,234,364$ \\
\hline $9,980,477$ & $3,887,300$ & $2,194,897$ & $3,665,476$ & $8,315,188$ & $7,502,839$ & $50,188,228$ \\
\hline 998,048 & 388,730 & 219,489 & 366,548 & 831,519 & 750,284 & $5,018,823$ \\
\hline
\end{tabular}


These figures do not include the regular charges for operating the forest protection services, they do not include the losses entailed in the partial or total cessation of forest industry in the districts where losses were suffered, nor do they include the inevitable potential loss in wages and production values occasioned by these fires.

From Table I it will be observed that, beginning in 1929, four successive seasons of unusual severity occurred, notable for the increasing number of fires reported. As previously explained, in these years the prevailing weather ronditions were extreme, because of lack of winter and spring precipitation. As a result, fires, once started, spread rapidly, covering large areas and making control measures both difficult and costly. The worst season since 1923 occurred in the year 1932 (the low point of the world depression), at which time protection staffs functioned at minimum strengths, and only expenditure for actual fire-fighting increased.

In considering the causes underlying forest destruction by fire there are two classes of risk to which Canada's forests are subjected, namely, natural risk and artificial risk. The former comprises chiefly lightning, while the latter refers to conditions created by human agencies, which constiute the main source of fires, as the following statement will show:-

TABI.E II-STATEMENT OF FIRES BY CAUSES FOR 10-YEAR PERIOD 1925-1934, IN CANADA

\begin{tabular}{|c|c|c|c|c|c|c|c|c|c|c|c|c|c|}
\hline \multirow[b]{2}{*}{ Cause } & \multicolumn{10}{|c|}{ Year } & \multirow[b]{2}{*}{ Total } & \multirow[b]{2}{*}{$\begin{array}{l}\text { Per } \\
\text { cent }\end{array}$} & \multirow{2}{*}{$\begin{array}{c}\text { Average } \\
\text { annual } \\
\text { number } \\
\text { of } \\
\text { fires by } \\
\text { causes, } \\
1925-1934\end{array}$} \\
\hline & 1925 & 1926 & 1927 & 1928 & 1929 & 1930 & 1931 & 1932 & 1933 & 1934 & & & \\
\hline Camp-fires. & 944 & 999 & 669 & 814 & 1,332 & 1,256 & 1,540 & 1,302 & 1,202 & 1,111 & 11,169 & 19 & 1.117 \\
\hline Settlers.... & 692 & 763 & 532 & 728 & 769 & 966 & 1,095 & 1,385 & 1,265 & 946 & 9,141 & 16 & 914 \\
\hline Lightning. . & 978 & 823 & 716 & 485 & 1,167 & 1,482 & 880 & 651 & 940 & 957 & 9,079 & 15 & 908 \\
\hline Smokers...... . & 531 & 513 & 369 & 500 & 856 & 762 & 937 & 809 & 893 & 971 & 7,141 & 12 & 714 \\
\hline Railways..... & 711 & 1,129 & 574 & 752 & 1,011 & 731 & 624 & 254 & 312 & 255 & 6,453 & 12 & 645 \\
\hline Unknown. . . . & 714 & 729 & 337 & 320 & 637 & 553 & 607 & 641 & 725 & 655 & 5,918 & 10 & 592 \\
\hline Incendiary.... & 204 & 167 & 95 & 230 & 387 & 521 & 673 & 746 & 511 & 349 & 3,883 & 7 & 388 \\
\hline Miscellaneous & & & & & & & & & & & & & \\
\hline known ..... & 431 & 260 & 130 & 227 & 240 & 276 & 367 & 243 & 300 & 365 & 2,839 & 5 & 284 \\
\hline Industrial & & & & & & & & & & & & & \\
\hline operations... . & 257 & 247 & 129 & 170 & 206 & 160 & 134 & 91 & 139 & 198 & 1,731 & 3 & 173 \\
\hline Public works. . . & 28 & 60 & 54 & 35 & 80 & 98 & 97 & 73 & 11 & 104 & 640 & 1 & 64 \\
\hline Total. & 5,490 & 5,690 & 3,605 & 4,261 & 6,685 & 6,805 & 6,954 & 6,295 & 6,298 & 5,911 & 57,994 & 100 & 5,799 \\
\hline
\end{tabular}

From Table II it will be observed that 15 per cent of all forest fires starting in the past ten years were due to lightning or other natural causes; the remainder ( 85 per cent) are attributed to human carelessness. The control of man-caused fires is possible, but the extent to which success may be 
attained will depend firstly upon the funds provided for the organization and equipment of efficient protection services, and secondly, and most important of all, upon the co-operation of the forest users.

Any relaxation of effort, due to decrease in funds or staff, may mean that the result of many years of relatively successful protection operations may be wiped out in a single season of serious fire-hazard. Furthermore, the final cost of suppressing forest fires is much greater if they are permitted to attain large size before organized effort for suppression is exerted. True economy in times of depression, as in times of prosperity, is secured when every person entering the forest on business or pleasure takes the necessary precautions against the starting and spread of fires.

Fire prevention, which means most of all the elimination of carelessness by the forest users, is the most effective means of reduction, both of fire losses and of costs of fire protection.

\section{CONCLUSION}

A review of the six-year period 1929 to 1934 shows that some progress has been made in fire protection in Canada. During 1929 and 1930 the various protection services were not handicapped by the financial restrictions which later ensued. In fact, the year 1930 reached a high point in the development of fire-protection organization in this country, witnessing an extension of forest improvements and additions of staff and equipment to areas formerly lacking these facilities of organized protection. From 1931 on, these gains were turned into losses. The economic depression brought in its wake curtailed expenditures and reduction in protection staffs below minimum requirements for normal fire years. All this occurred in years of critical fire danger. Such advances as were noted in the period under consideration were confined entirely to organization for the detection and suppression of fires starting. The most important phase of fire protection, namely, forest fire prevention was largely neglected. In these circumstances the forest authorities view with concern the fire situation in Canada as it exists to-day. 